\title{
An Analysis of the Hierarchy of Goals that Guides the Consumer's Decision to Attend Shopping Malls: a Contrast Between Men and Women
}

\author{
Silvana Taschek Hastreiter ${ }^{\dagger}$ \\ Pontifical Catholic University of Paraná \\ Renato Zancan Marchetti ${ }^{\Omega}$ \\ Pontifical Catholic University of Paraná
}

\begin{abstract}
Understanding the hierarchy of goals of the consumer is one of the issues that has guided the efforts of researchers in recent years. The objective of this study is to identify a hierarchy of goals that guides the decision of men and women to visit shopping malls. A study was conducted over a qualitative and a quantitative stage, using the Association Pattern Technique and log-linear model. In the qualitative research, 14 consumers who reside in Curitiba-PR were interviewed resulting in 42 narratives and 90 reports of visits to the mall. In the quantitative stage, with electronic data collection, we obtained a sample of 703 valid questionnaires from consumers of 66 Brazilian cities. We found that men and women go to shopping malls with different motivations and therefore have different goal structures. Men have a more utilitarian motivation, and visit malls with specific goals for the accomplishment of some task. Women, on the other hand, go to malls with more hedonic motivations. They value the comfort and pleasure that malls provide.
\end{abstract}

Keywords: Hierarchy of consumer's goals. Hedonic and utilitarian shopping values. Gender. shopping malls.

†. Doctor by Pontifícia Universidade Católica do Paraná Institution: Professora Adjunta da Pontifícia

Universidade Católica do Paraná

Adress: Rua Imaculada Conceição, 1155, Curitiba - PR

- Brazil - CEP: 80215-901

E-mail: silvana.hastreiter@pucpr.br

Telephone: + 55 (41) $32712559 \mid+55$ (41) 99836987

\footnotetext{
${ }^{\Omega}$ Docteur ès Sciences de Gestion pela École des Hautes Commerciales HEC PARIS Institution: Professor Titular da Pontifícia Universidade Católica do Paraná Adress: Rua Imaculada Conceição, 1155, Curitiba - PR - Brazil - CEP: 80215-901 E-mail: renato.zancan@pucpr.br Telephone: + 55 (41) 32712131
} 



\section{INTRODUCTION}

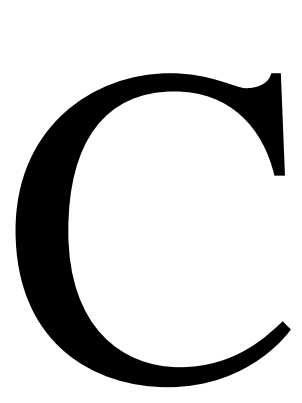

onsumer's behavior is fundamentally orientated towards goals, which are desired which one intends to reach (BAGOZZI; DHOLAKIA, 1999; ARIELY, 2008). Goals consist of cognitive representations of personal motivation (BANDURA, 1986) or intentions to reach desired ends (MOSKOWITZ; GRANT, 2009) through the consumption of goods or services (GABARINO; JOHNSON, 2001), attitudes (BAGOZZI; DHOLAKIA, 1999), or by carrying out actions (VAN OSSELAER et al., 2005).

Based on the principal of goal determination, these may utilitarian or hedonic. Utilitarian goals are related to the performance of tasks or the purchase of products to achieve a particular purpose (BOTTI; MCGILL, 2011) and the purchase is motivated by functional aspects and tangible characteristics (BABIN; DARDEN; GRIFFIN, 1994; KHAN, DHAR; WERTENBROCH, 2005). Hedonic goals though, consist in a reward or personal gratification BABIN; DARDEN; GRIFFIN, 1994) and are associated with satisfaction of fantasies, entertainment, pleasure and enjoyment obtained from the shopping experience (MICHON; CHEBAT, 2004; BOTTI; MCGILL, 2011).

In recent years, researchers began to identify consumer's hierarchy goals, having as their focus the decision process of purchase of specific products or services such as: property (SCHAUERTE, 2009), food (HESS, MARCHETTI, 2011), auto mobiles (ESCUDERO; PRADO, 2008), entertainment (PARK; SMITH, 1989). Lee and Ariely (2006) widened the perspective of product focus and conducted a study in a convenience store. However, so far we did not find in the literature examples of studies in complex retail establishments that enable the achievement of various goals and at different hierarchical levels.

When it comes to complex retail, the most notorious ones are shopping malls, which is an enterprise built for the consumer to engage in various activities in addition to shopping, such as: eating, making use of the services offered, socializing with friends and getting to know other people, attending events or simply passing the time (BLOCH; RIDGWAY; DAWSON, 1994). Therefore, a shopping center allows consumers to achieve both utilitarian as hedonic goals (BABIN; DARDEN; GRIFFIN, 1994).

The genre has been the subject of studies focusing on purchasing behavior in retail environments both offline (BARLETTA, 2006; UNDERHILL, 2009; 2010) as online 
(GARBARINO; STRAHILEVITZ，2004; DAVIS， LANG，SAN DIEGO，2014) and differences were observed in the purchasing behavior of men and women.

In this study, the research problem is to understand the hierarchy of goals that guides the consumers' decision to go to shopping malls. The main objective sought to verify whether this structure varies between men and women.

The relevance of this approach is justified for its originality, because there is no hierarchy of goals in studies of complex retail environments and also the importance of the shopping center segment in the Brazilian economy, given that it represents $19 \%$ of retail sales, employing approximately 900.000 people in 518 establishments associated with ABRASCE Brazilian Association of Shopping Centers. More than 400 million consumers attend these establishments on a monthly basis, a turnover that provides a growth in sales of around $8 \%$ per annum, much higher than the GDP growth (ABRASCE, 2014).

The paper is organized into four sections: initially we present a brief literature review that that aims to update the reader on the theoretical framework developed on consumer goals and their hierarchical organization and the identified differences, in previous studies, with respect to gender relationships and consumption. Following that, we present the methodological procedures and the main results of each of the three stages of research. Finally, we present our final considerations and the theoretical contribution and the possibilities of managerial application.

\section{THEORETICAL REVIEW}

\subsection{THE CONSUMER'S HIERARCHY OF GOALS}

According to Bagozzi and Dholakia (1999), a major part of consumer's behavior is goal-oriented, whether in relation to durable goods, non-durable goods, services or ideas. All of these goals focus in a specific result that may be produced through consumption or attitudes. Thus a goal consists in what a person wants at a given moment and it involves a sequence of actions with the intent to achieve this goal (MCINTOSH, 1996).

This process of the consumer's choices can be organized in a hierarchically manner and varies from a more concrete level to a more abstract level of attending needs (GUTMAN, 1982, 1997). One of the traditional ways to identify the structure goals is through the MeansEnd Chain Model (MEC) which focuses on the relationship between product attributes, the consequences or perceived benefits and the consumer's desired end state (GUTMAN, 1997). 
The most prominent classifications in literature, proposed proposals to understand the levels that make up the hierarchy of goals are the ones by Bagozzi and Dholakia (1999) and the hierarchical model by Huffman, Ratneshwar and Mick (2000). Both use three different levels, but with different constructs.

Bagozzi and Dholakia (1999) seek to identify how a specific goal is connected to the impulse/reason to act. Goals are hierarchically organized in levels of motive-goals (what is sought), subordinate (how to achieve what is sought) and higher (the reason for achieving what is sought).

Huffman, Ratneshwar and Mick (2000) consider the dynamic nature of goals and proposed a framework with three levels that were grouped in six distinct dimensions: HAVE (preferred characteristics and benefits), DO (current concerns and intent of consumption) and $\mathrm{BE}$ (values and projects and motives of life) having as a reference the principles of the Means-End Chain (MEC) which considers ascending sequence of links between attributes, consequences and values (GUTTMAN, 1982).

This structure offered a great theoretical contribution, in practice however, it presents difficulties of operationalization once that two dimensions (preferred characteristics and benefits), which correspond to the level HAVE, conflict with the fundamental premises of the MEC which considers attributes and benefits as different levels of abstraction (GUTMAN, 1982; 1997; HOFSTEDE et al., 1988). Huffman, Ratneshwar and Mick (2000) consider that people acquire possessions in order to take them towards the fulfillment of their ideals of life. In this perspective, level DO focuses in the actions seeking an outcome that leads to the realization of life projects. Gutman (1982) and Hofstede et al. (1998) define as consequences these results that product's attributes provide the consumer in a given situation. These consequences can be positive as well as negative. These positive consequences, authors call benefits. Thus, benefits are in a level of abstraction different to those of the product's attribute, for they are related to the consequences that these provide and that, in turn, are related to values and motives of personal life. Ligas (2000) simplified these models in three levels and adapted them for use in various products. He considered level HAVE as products' characteristics, the level DO as consequences or intended benefits, and the level BE as the motive of life or values that guide consumer's choices.

In this study we propose keeping the three conceptual levels (HAVE, DO and BE) from the model by Huffman, Ratneshwar and Mick (2000) considering the simplification proposed by Ligas (2000) and, using as a reference other studies that contributed to widen knowledge 
of the hierarchy of goals based on the laddering technique (BAGOZZI; DHOLAKIA, 1999; HOUSTON; WALKER, 1996; PARK; SMITH, 1989; GUTMAN, 1997; LEE; ARIELY, 2006; ESCUDERO; PRADO, 2008; SCHAUERTE, 2009), we will seek to identify the sequential relationship between Attributes, Benefits and Values (A-B-V) that guide the decision making process of men and women to achieve utilitarian and hedonic goals in shopping malls.

We will consider the level HAVE as the consumer's determination to attend a shopping mall in search of products or to perform specific activities according to the characteristics and attributes that they present. The level DO consists in the consumer's desire to achieve a result in a given situation. Such are the desired consequences or benefits that the consumer expects that the characteristics and attributes that the mall would provide them. And the level BE is the most abstract one of the goal structure and it is related to the values and motives of life that guide consumer's behavior.

In this study we seek to identify whether men and women present different associations between the levels HAVE, DO and BE in their decision to attend shopping malls. The following topic provides an overview of the gender's major differences identified in research on consumer behavior.

\subsection{GENDER AND CONSUMER RELATIONSHIPS}

Studies on consumer's behavior identified gender differences in the motivational orientation and in the intent of purchase (BARLETTA, 2006; UNDERHILL, 2009; 2010; KRAFT; WEBER, 2012; DAVIS; LANG; SAN DIEGO, 2014). These results indicate that men and women seek different results in the process of purchase decision. Women are more driven by hedonic aspects, prioritize shopping experience, they like to move around the store and react more intensely to contact with sellers. They are more detail-oriented, they do more research, seek more information and like to try and compare products, brands and prices before buying a product. They are more judicious in evaluating the cost/benefit of the purchase and seem to have fun with this process.

Men however are more focused on utilitarian and concrete aspects of the experience, such as: parking space, product availability and checkout queues. They tend to be more objective, they consider the act of purchasing as a task to be fulfilled and leave as soon as they have done it. They are more impatient, they do not spend time appreciating other items in addition to those they sought, they ask for less information and leave the store as soon as they 
find the product. They are practical and objective and appear to feel less pleasure and have lees fun in the buying process.

Davis, Lang and San Diego (2014) measured the differences in gender when purchasing online and offline and identified more expressive differences in offline environments. The results confirm a more hedonic motivation from women and a more utilitarian one from men. However, the technological interface reduces the hedonic experience, leading the behavior of women closer to that of men, focusing on aspects that are more rational and utilitarian. It is worth highlighting some gender differences in online shopping: women perceive greater risk than men do and at the same time, are more susceptible to the recommendations and positive reviews (GARBARINO; STRAHILEVITZ, 2004) and negative (ZHANG, FEICK, MITTAL, 2014).

\section{METHODOLOGY}

To identify the motivational aspects related to the hierarchy of goals that guide the consumers' decision process in a shopping mall, we used a multi-method approach with three research stages: two qualitative and one quantitative. The qualitative stages (in-depth interviews and mall visit reports), of exploratory nature, had as their main objective comprehending the dimensions related to the three levels that compose consumers' hierarchy of goals to attend shopping malls. The quantitative stage, of confirmatory nature, had as its main objective quantifying the existent relationships between the levels of the hierarchy of goals and to identify the existing differences between men and women.

\subsection{QUALITATIVE STAGE 1 - IN-DEPTH INTERVIEWS}

For an exploratory analysis of the consumer goals structure in shopping malls, we selected men and women who are used to attending shopping malls at least once a week criterion sampling (PATTON, 2002). We opted for this definition because $64 \%$ of consumers attend shopping malls weekly (ABRASCE, 2013). The sample consisted of seven men and seven women of class $\mathrm{A}$ and $\mathrm{B}$ living in Curitiba-PR, Brazil. In order to reach a representativeness of different age so there is heterogeneity of views between the interviewees public, the sample was composed as follows: two men between 17-34 years old, two between 35-45 years old and three over 45 years of age; three women between 17-34 years old, two between 35-45 and two older than 45 years of age. The interviews we conducted between May and August 2011 and lasted in-between 1:30-2 hours long.

We conducted an in-depth interview using the laddering technique (REYNOLDS; GUTTMAN, 1988) and the autodriving technique (HEISLEY; LEVY, 1991). The laddering 
technique or climbing, consists in developing questions that seek to relate more concrete targets with its more abstract aspects to build chains of meaning as to how Attributes lead to expected consequences or Benefits, which lead us to Values or expected end states (A-B-V). Since the aim of the climb is to discover the most complete possible chain (GUTMAN, 1997), the questions climb up in the abstraction level (what, how, why, what for) until the respondent can no longer find an answer (GUTMAN, 1982, REYNOLDS; GUTMAN, 1988). To guide this chain of questions, we developed three scenarios of consumption based on the purchasing process extension criteria by Engel, Blackwell and Miniard, (2000): usual decision process, limited and expanded, as shown in Table 1.

\begin{tabular}{|c|l|}
\hline DECISION MAKING & Think of something you set out to do in a shopping mall.... \\
\hline Customary & $\begin{array}{l}\text {..something that suits your life style, in which you feel comfortable in doing and } \\
\text { that you do frequently. Think of the reasons of why you chose the shopping mall } \\
\text { in order to do that and how fun and enjoyable, on how easy/difficult it was to find } \\
\text { it and how easy/difficult it was in deciding on the best choice in this mall. }\end{array}$ \\
\hline Limited & $\begin{array}{l}\text {..that needed to be done, even if it were something boring or monotonous. Think } \\
\text { about the reasons why you chose the mall for that and in how familiar this seemed } \\
\text { for you, on how much information you had to go after and what were the } \\
\text { consequences if you made the wrong choice. Think about how easy/difficult to } \\
\text { find it and how easy/difficult it was to make the best choice. }\end{array}$ \\
\hline Expanded & $\begin{array}{l}\text {...once you spent hours in the mall and visited several stores, you analyzed } \\
\text { countless brands and you could not decide easily what was your best choice. } \\
\text { Think about the reasons why you chose the mall for this particular thing and how } \\
\text { important this purchase was for you, what the sought product or service means to } \\
\text { you and what it says about you before other people. Think about how } \\
\text { pleasurable/painful this purchase was and how safe or unsafe you felt regarding } \\
\text { your choice. }\end{array}$ \\
\hline
\end{tabular}

Table 1: Consumption situations that guided the interviews

Source: Developed by authors.

Autodriving is a stimulating technique that encourages consumers to comment on their consumption behavior by using images, photos or recordings that represent them (HEISLEY; LEVY, 1991). We requested respondents to separate images that helped to better portray each situation. As thinking retrospectively can generate memory biases (MICK; BUHL, 1992), by asking respondents to bring an image helps transform an abstract story in a more concrete narrative (ZALTMAN, 1997).

Each surveyed respondent was questioned about three experiences of consumption in shopping malls; with 14 interviews we obtained 42 narratives, which proved fairly consistent, 
then the content became repetitive, up until the point of redundancy (PATTON, 2002) or saturation of the information collected (FLICK, 2004).

We conducted a content analysis of the interviews in order to identify consistency and meanings of the reports (PATTON, 2002).

\subsection{QUALITATIVE STAGE 2 - SHOPPING MALLS VISIT REPORTS}

In order to better understand the consumer's goal structure and identifying the strongest associations between goals and the means to it, the shopping mall, the same 14 respondents, residents in Curitiba-PR, took part in the second stage, during which a script was handed to them to do a self-report, that is, to fill in a visit dairy, stating what they were doing at the mall and why they chose it for this purpose. This survey was conducted over a four-week period, during September 2011, where we obtained from 4 to 18 reports per respondent, amounting to 90 shopping mall visit reports.

In order to interpret the content of the narratives we established categories of analysis that underlie the interpretation (BARDIN, 1994). As a theoretical framework, we adopted the structure of goals by Huffman, Ratneshwar and Mick (2000) and the adaptations proposed by Ligas (2000), considering the levels HAVE (attribute and characteristics associated to the mall), DO (desired outcome - consequences or benefits) and BE (values and life projects). Also denominated as soft laddering, this stage consist in the use of qualitative techniques to survey the A-B-V chain (HOFSTEDE et al., 1998) and it served as a base to develop the questionnaire of the quantitative stage.

\subsection{QUANTITATIVE STAGE - SURVEY}

This stage corresponds to a descriptive research in which, through a questionnaire made available through an electronic format (Qualtrics system), the hard laddering was used, that is, a quantitative approach to collect Means-End chain type of data, in a more structured process during data collection (HOFSTEDE et al., 1998).

The objective of this stage was to quantify the existent relationships in the exploratory stage through the Association Pattern Technique (APT) technique which seeks to measure the relationship between the levels HAVE, DO and BE in an individual manner. The result is a binary matrix containing existent and non-existent relations.

In order to increase the response rate in a short period of time (from December 2011 till January 2012), we offered the respondents a monetary incentive of $\mathrm{R} \$ 500,00$ which would be drawn at the end of the data collection (post incentive). Although there are restrictions on the 
use of incentives, to provide a tangible benefit for respondents increases response rate in electronic research (COBANOGLU; COBANOGLU, 2003; GORITZ, 2006).

1.121 questionnaires were initiated. After a critical analysis and the disposal of the unfinished, non-identified questionnaires, the ones that were answered in less than 10 minutes and the outliers, we obtained a sample by accession of 703 validated questionnaires, composed by $\mathbf{2 4 6}$ men and $\mathbf{4 5 7}$ women. The respondents come from 66 cities in Brazil, with the highest concentration in the South region (84.9\%), $11.2 \%$ in the Southeast region and the remaining $3.8 \%$ were distributed in the North, Northeast and Midwest region of Brazil.

For the analysis of the hierarchy of goals we followed the recommendations by Reynolds and Gutman (1988) and Hofstede et al. (1998) that consist in the development of Implication Matrices and of Hierarchical Value Maps (HVM). To develop the Implication Matrices we extracted the frequency of the perceived associations between A-B and B-V. These implication matrices served as a base to develop HVMs.

Despite a quantitative stage, the cutting criterion to identify which relationships to include in the HVM is a critical and subjective factor, determined by the researcher. We decided to consider multiple criterions, considering only the relationships that met the four cutting criterion: 1) The sample divided into proportional parts, setting the 75th percentile to highlight the relationships to be considered; 2) representativeness $\geq 1 / 3$ of the sample (percentage in the line of the implication matrix in relation to the respondents base); 3) explanatory power in line $\geq 10 \%$ (percentage in relation to the sum of the frequencies in the implication matrix); 4) Matrices independence AB and BV.

To test the independence of matrices $\mathrm{AB}$ and $\mathrm{BV}$ a loglinear model was formulated, whose goal is to study the relationship between qualitative variables (EVRARD; PRAS, ROUX, 2009). In the model in question, we tested the statistical probability of the relationships of the chains in relation to the saturated model $[\mathrm{ABV}]$ :

$$
\mathrm{Ln} \mathrm{P}_{\mathrm{ijk}}=\alpha+\gamma_{\mathrm{ij}}^{\mathrm{AB}}+\gamma_{\mathrm{jk}}^{\mathrm{BV}}+\gamma_{\mathrm{ik}}^{\mathrm{AV}}+\delta_{\mathrm{ijk}}^{\mathrm{ABV}}
$$

To view the A-B-V relationships that meet all of these criterions the HVMs were built from the motivations of men and women to attend Brazilian shopping malls. To set the intensity of relations we took the relationships belonging to the 75th percentile, considering up to the 33rd percentile as mild relations, between percentiles 34 and 65 as being of moderate intensity and from the 66th percentile as being of high intensity. 
To identify the predominant motivational orientation a Confirmatory Factor Analysis (CFA) was done from the scale developed by Babin, Darden and Griffin (1994) using the AMOS software. Although the scale has already been applied in studies by Michon and Chebat (2004) in Canada and by Davis, Lang and San Diego (2014) in New Zealand, to verify its effectiveness in the Brazilian context we used the back translation technique which consists in translating the items to Portuguese and then translating it back into English to confirm that all phrases kept their original sense of the scale. After adjusting for a better configuration of the model, we performed the two-step cluster procedure (available on SPSS 20) to allocate respondents in a homogeneous group in terms of dominant motivational orientation to go to the mall.

\section{RESULTS AND DISCUSSION}

\subsection{QUALITATIVE STAGE - IDENTIFYING CONSUMER'S STRUCTURE OF GOALS IN A SHOPPING MALL}

From the content analysis of the 90 visits reports more than 60 different activities were identified in which the respondents carried out at the mall during the month of monitoring. Malls are frequented both for the achievement of utilitarian goals, whose focus is on the task and on problem-solving, as well as selecting malls in order to reach hedonic goals, whose focus in on the consumption experience and on the pleasure that it provides (HIRSCHMAN; HOLBROOK, 1982; BABIN; DARDEN; GRIFFIN, 1994; BOTTI; MCGILL, 2011). In short, the most cited reasons for attending shopping center, also identified by content analysis that can be grouped into four categories: a) purchase, b) food, c) leisure and d) services. A result that is consistent with the data published by ABRASCE (Brazilian Association of Shopping Centers), with ICSC (International Council of Shopping Centers) and with numerous studies conducted in other countries (BLOCK; RIGWAY; DOWSON, 1994; EL-ADLY, 2007; HASTREITER; MARCHETTI, 2013). All of these studies point to a homogeneous pattern of use of shopping malls. However, when analyzing the consumers' structure of goals, we identify that there are different perceptions on motivation when attending them.

This exploratory stage identified the main goals that the consumer seeks to reach in a shopping mall in different levels of abstraction. In the level HAVE we find the attributes and the determining characteristics in the consumer's decision to attend malls. Among the numerous aspects identified in interviews and visit reports, we synthesized 13 attributes which can be classified into six dimensions, all of which are widely supported in national and international studies and disseminated by the ICSC and the ABRASCE - set of stores that are present in the mall or tenant mix, leisure, location and infrastructure, opening hours, retail 
environment or mall essence (comfort, decor, lighting, air conditioning, etc.) competitive prices and promotions.

\begin{tabular}{|c|c|c|}
\hline HAVE GOALS & DO GOALS & BE GOALS \\
\hline Attributes and characteristics & Consequences/perceived benefits & Values and life projects \\
\hline $\begin{array}{l}\text { Variety of shops - many options in } \\
\text { one place. }\end{array}$ & PROBLEM SOLVING & $\begin{array}{l}\text { Family harmony - united and } \\
\text { happy family. }\end{array}$ \\
\hline Variety of dining options & $\begin{array}{l}\text { Practicality - doing several things at } \\
\text { the same place. }\end{array}$ & $\begin{array}{l}\text { Life quality, well-being, living } \\
\text { more and healthy }\end{array}$ \\
\hline $\begin{array}{l}\text { Leisure facilities and entertainment } \\
\text { options - movies, toys, games, etc. }\end{array}$ & $\begin{array}{l}\text { Comfort and convenience }- \text { stroll } \\
\text { with children, breastfeeding, etc }\end{array}$ & Personal fulfillment \\
\hline $\begin{array}{l}\text { Access and parking - easy to get to } \\
\text { and park the car. }\end{array}$ & $\begin{array}{l}\text { Peace of mind and safety - carefree } \\
\text { walk, feeling safe to shop }\end{array}$ & To be an admired person \\
\hline Location - close to home or work & $\begin{array}{l}\text { Maximize the use of time - sort things } \\
\text { out quickly and have time for other } \\
\text { things that provide pleasure }\end{array}$ & To succeed professionally \\
\hline $\begin{array}{l}\text { Extended opening hours (evenings } \\
\text { and weekends) }\end{array}$ & Possibility to compare prices & Recognition/Acceptance \\
\hline Public who attends the mall & VALUE EXPRESSION & Happiness, joy \\
\hline $\begin{array}{l}\text { Shops' decoration, shop windows } \\
\text { and products display }\end{array}$ & $\begin{array}{l}\text { Conciliate interests/tastes/family } \\
\text { wishes in one place. }\end{array}$ & $\begin{array}{l}\text { Affectivity - show love, affection, } \\
\text { recognition and gratitude. }\end{array}$ \\
\hline $\begin{array}{l}\text { Wide corridors and comfortable } \\
\text { structure (benches to sit, baby } \\
\text { facilities, cafes, etc.) }\end{array}$ & $\begin{array}{l}\text { Up-to-date - seeing fashion trends, } \\
\text { news }\end{array}$ & $\begin{array}{l}\text { Independence, autonomy, } \\
\text { individuality }\end{array}$ \\
\hline $\begin{array}{l}\text { Pleasant atmosphere, clean, safe, air- } \\
\text { conditioned, well-lit, protected from } \\
\text { the weather. }\end{array}$ & Status - mall stores appear to be best & Spirituality, peace \\
\hline $\begin{array}{l}\text { Service options (hairdressers, banks, } \\
\text { fitness center, pet shop, Wi-Fi, etc.) }\end{array}$ & Family life & $\begin{array}{l}\text { Conscious consumption - } \\
\text { responsibility in shopping, do not } \\
\text { buy superfluous items }\end{array}$ \\
\hline Competitive prices and promotions & Social life & \\
\hline Brands/shops' exclusive labels & Pleasure/personal gratification & \\
\hline
\end{tabular}

Table 2 - Goals HAVE, DO and BE in a Shopping Mall

Source: Developed by authors.

Going up in the abstraction level, the level DO brings together the benefits that consumers expect to achieve from these attributes and characteristics associated with the shopping mall. 11 benefits were identified, which can be grouped within problem solving DO goals and value expression DO goals (LIGAS, 2000). For problem solving we have the following benefits: practicality, comfort and convenience, peace of mind and safety, maximizing the use of time, being able to compare prices. Benefits associated to relevant personal aspects can be classified as value expression DO goals, such as: conciliate interests, up-to-date, status, family life, social life, pleasure and self-gratification. 
In the level of goals $\mathrm{BE}$ we identified 11 personal meanings that consumers attribute to these benefits, which are related to their values and life projects.

Table 2 present a synthesis of the attributes, benefits and values that were identified in the qualitative stage. The results of the in-depth interviews and the visits reports reveal the elements of the consumer's goals in a shopping mall. The quantitative stage aims to identify the relationship between the hierarchical levels of consumers and to identify whether there are differences in the structure of the relations of men and women's goals.

\subsection{QUANTITATIVE STAGE}

\subsubsection{Motivations for attending a shopping mall}

The dominant motivation to attend shopping malls was identified based on the Personal Shopping Value scale (BABIN; DARDEN; GRIFFIN, 1994). In order to validate the scale in the context of this study we used a confirmatory factor analysis following the guidelines by Hair Junior et al. (2005) where the $\chi^{2} / \mathrm{df}$ should be lower than 5.0 and also by Byrne (2011) of which the model Parsimony Goodness-of-Fit index value (PGFI) should be above 0.5 and the critical values for the items remaining in the scale should be $\geq-1.96$ at p-level 0.05 .

Several attempts were made until we found the best adjustment of the model, with compound reliability indexes (CONF) above 0.7 and Average Variance Extracted (AVE) higher than 0.5 . The compound reliability is an indicator of convergent validity and the average variance extracted is a summary indicator that checks the explanatory power of the indicators of a latent variable (HAIR JUNIOR et al. 2005).

Of the 15 original items of the scale, 8 remained in that model, confirming results from previous studies (BABIN; DARDEN; GRIFFIN, 1994; MICHON; CHEBAT, 2004; DAVIS; LANG; SAN DIEGO, 2014) dividing into two dimensions - Hedonic and Utilitarian motivation. The results of the correlation matrix are presented in Table 3 and signal positively the convergent and discriminant validity of the scale. 
Table 3 - Correlation Matrix - Utilitarian and Hedonic Dimensions

\begin{tabular}{|c|c|c|c|c|c|c|c|c|c|c|}
\hline & Hedonic Uti & litarian & 12 & 14 & 1 & 3 & 4 & 7 & 9 & 11 \\
\hline Hedonic & 1,000 & & & & & & & & & \\
\hline Utilitarian &,- 407 & 1,000 & & & & & & & & \\
\hline 12 &,- 342 & ,840 & 1,000 & & & & & & & \\
\hline 14 &,- 293 & ,719 & 604 & 1,000 & & & & & & \\
\hline 1 & ,869 &,- 353 &,- 297 &,- 254 & 1,000 & & & & & \\
\hline 3 & ,782 &,- 318 &,- 267 &,- 229 & 679 & 1,000 & & & & \\
\hline 4 & ,739 &,- 301 &,- 253 &,- 216 & ,642 &, 578 & 1,000 & & & \\
\hline 7 & ,672 &,- 273 &,- 230 &,- 197 &, 584 & ,525 & ,497 & 1,000 & & \\
\hline 9 & ,610 &,- 248 &,- 208 &,- 178 &, 530 & ,477 & ,451 & ,410 1 &, 000 & \\
\hline 11 & ,576 &,- 235 &,- 197 &,- 169 &, 501 & ,450 & ,426 & ,387 & ,351 & 1,000 \\
\hline
\end{tabular}

Source: Developed by authors

The factor loadings, compound reliability (CONF) and the average variance extracted are shown in Table 4. The magnitude of the factor loading above 0.50 in a sample with 703 cases indicates the suitability of the items as representation of the factor (HAIR JUNIOR et al, 2005).

Table 4 - Factor Loading, CONF and AVE - Utilitarian and Hedonic Dimensions

\begin{tabular}{|c|c|c|}
\hline \multirow[b]{2}{*}{ ITEMS } & \multicolumn{2}{|c|}{ MOTIVATION } \\
\hline & HEDONIC & UTILITARIAN \\
\hline 1-Going to the mall is a truly joy for me. & 0,867 & \\
\hline 3-A trip to the mall truly felt like an escape. & 0,782 & \\
\hline $\begin{array}{l}\text { 4- Compared to other things I could do otherwise, the time I spend at the mall is } \\
\text { pleasurable. }\end{array}$ & 0,739 & \\
\hline 7- I have fun at the mall because I let myself be carried away by the moment. & 0,672 & \\
\hline 9- Whilst I shop at the mall, I forget my problems. & 0,610 & \\
\hline 11- My shopping trips are usually very pleasurable moments. & 0,576 & \\
\hline 12-I'm used to doing at the mall only what I had planned to do. & & 0,840 \\
\hline 14- When I'm at the mall, I only buy items I was looking for. & & 0,719 \\
\hline CONF & 0,86 & 0,51 \\
\hline $\mathrm{AV}$ & 0,76 & 0,61 \\
\hline
\end{tabular}

Source: Developed by authors 
The absolute adjusted value $\chi^{2}$ stood at 50.13 with 19 degrees of freedom and significance level of 0.000 , which generated a value of $\chi^{2} / \mathrm{df}=2.64$ (within the acceptable value <5). The GFI 0.938, the NFI 0.977 and the CFI 0.985 are all measures considered satisfactory (close to 1.00) (BYRNE, 2001; HAIR JUNIOR et al, 2005). The parsimonious index of the model PGFI=0.669 also meets the premises of a good adjusted model, with a value above 0.5 (BYRNE, 2001) as well as the RMSE at 0.048 indicates a good approximation error adjustment between the matrices $(<0.08-$ HAIR JUNIOR et al, 2005).

To classify consumers based on the dominant utilitarian or hedonic motivation, we used the two-step cluster procedures and to identify whether the means of the responses are statistically different between groups, we used a One Way ANOVA with the post hoc Tukey test. The results indicate the existence of three groups of consumers: 1) those who go to the mall with predominant Hedonic motivation (30.7\%), that is, who value the consumer experience and the aspects related to leisure, entertainment and escapism; 2) predominant Utilitarian motivation (34.4\%) who are the consumers who do not expect to do other things at the mall or staying any longer after reaching their goal; 3) Mixed motivation (34.9\%) which brings together consumers who attend the mall with both utilitarian and hedonic motivation, that is, who seek convenience and the charm of shopping malls, considering them suitable both for problem solving as well as for fun and to escape the routine.

When analyzed by gender, it is clear that there is a different motivation between men and women. Men have more motivation to do the task and present predominant utilitarian motivation (45.9\%) and mixed (25.2\%). Among women a great part of them have mixed motivation $(40 \%)$ and hedonic $(31.7 \%)$ to go to the mall as shown in Table 5.

Table 5 - Dominant Motivation Among Men And Women To Attend Shopping Malls

\begin{tabular}{|c|c|c|c|c|c|c|}
\hline \multirow{2}{*}{$\begin{array}{l}\text { Gender } \\
\text { Predominant Motivation }\end{array}$} & \multicolumn{2}{|c|}{ TOTAL } & \multicolumn{2}{|c|}{ MEN } & \multicolumn{2}{|c|}{ WOMEN } \\
\hline & $\mathrm{n}$ & $\%$ & $\mathrm{~N}$ & $\%$ & $\mathrm{~N}$ & $\%$ \\
\hline HEDONIC & 216 & 30.7 & 71 & 28.9 & 145 & 31.7 \\
\hline UTILITARIAN & 242 & 34.4 & 113 & 45.9 & 129 & 28.2 \\
\hline $\begin{array}{c}\text { MIXED - hedonic and } \\
\text { utilitarian }\end{array}$ & 245 & 34.9 & 62 & 25.2 & 183 & 40.0 \\
\hline TOTAL & 703 & 100 & 246 & 35.0 & 457 & 65.0 \\
\hline
\end{tabular}


Considering the motivation as a continuum, the consumer may have a predominant orientation in one of the extremes of the scale as they can be located more towards the center, incorporating aspects of both constructs. This way, it can be considered that the scale is appropriate to classify customers according to their motivational orientation to go to the mall: whether they consider it to be a mandatory task, an entertainment or a mandatory task that can also be fun (BADIN; DARDEN; GRIFFIN, 1994).

The following presents how these differences impact the motivational structure governing decisions to attend malls.

\subsubsection{Hierarchies of goals to attend Shopping malls: contrasts between men and women}

The first step in identifying the hierarchy of goals is to develop the implication matrix frequency of the perceived associations between attributes and benefits and another for Benefits and Values/life projects (REYNOLDS; GUTMAN, 1988; HOFSTEDE et al., 1998). With the attributes, benefits and values/life projects identified in the qualitative stage, we reached a total of 264 chains, where 143 are among attributes and benefits $(A B)$ and 121 among Benefits and Values (BV).

The next step consists in identifying amongst all the relations, those that will compose the hierarchical value map (HVM). After evaluating the relations based on the four cutting criterion adopted $\left(75^{\text {th }}\right.$ percentile, representativeness $\geq 1 / 3$ of the sample, explanatory power $\geq$ $10 \%$ and the independence of the matrices $\mathrm{AB}$ and $\mathrm{BV}$ ), we identified the most prominent chains when attending malls.

It must be highlighted that a valid chain is the one that has a significant relationship between the levels HAVE and DO and between the levels HAVE and BE. Figures 1 and 2 graphically illustrate the hierarchical map of values of men and women. 


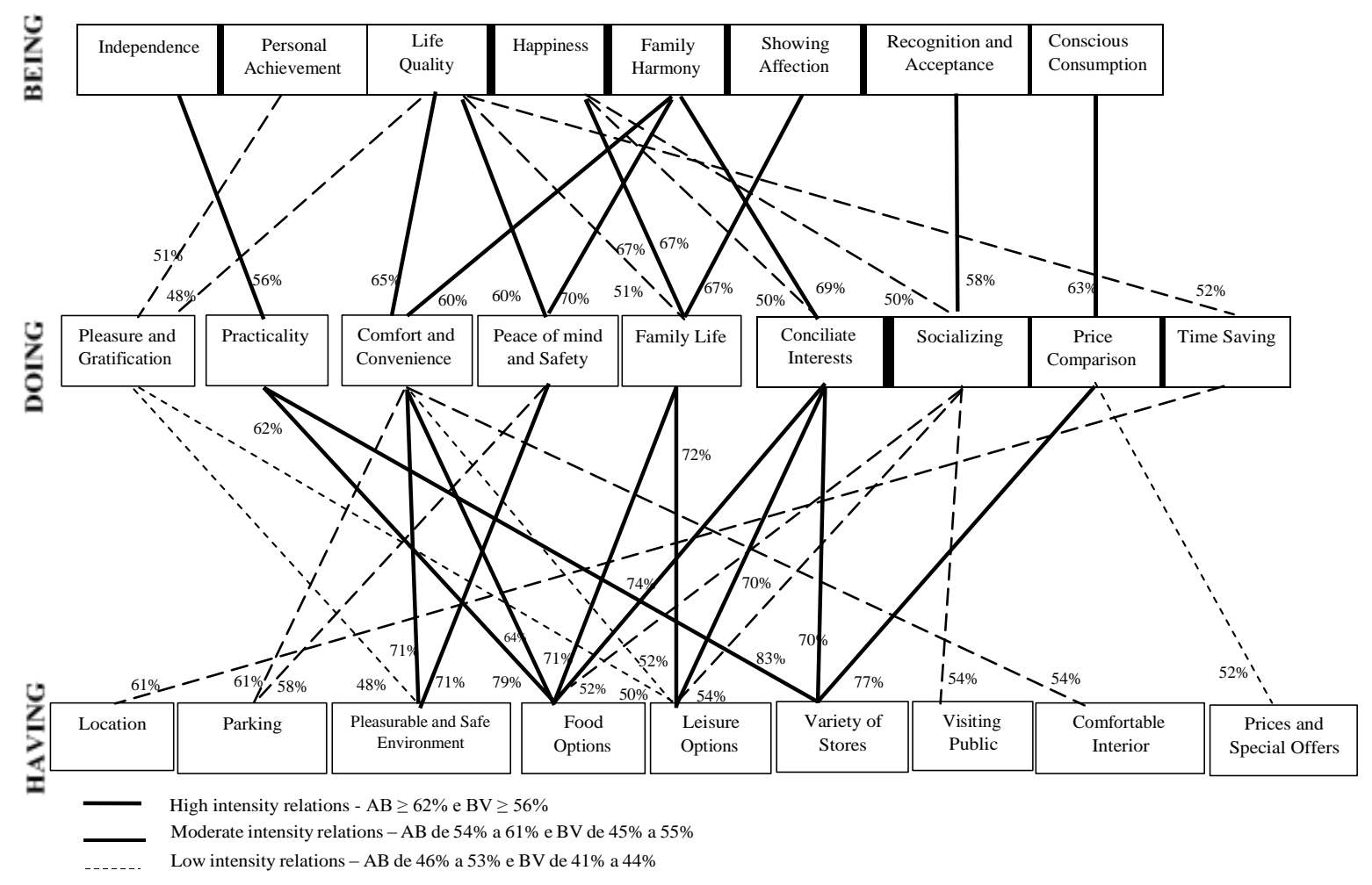

Basis: 246 male respondents

Figure 1 - Hierarchical Value Map - Men

Source: Developed by authors

For $71 \%$ of men, the attribute pleasurable and safe environment of the mall (level HAVE) provides the benefit of peace of mind and safety (level DO) and 70\% realize that this contributes to achieving the desired end state of family harmony (level BE). Family harmony is also the value associated with the benefits of conciliate interests and family wishes $(69 \%)$ and with family life $(67 \%)$. The family life benefit is also strongly associated with figures demonstrating affection (67\%) and happiness (67\%). Men perceive also that variety of stores (70\%) that the malls offer, the options in the food court (74\%) and leisure options $(70 \%)$ make it possible to conciliate interests and enjoy pleasant moments with family during their stay in the mall.

In addition to these dominant Means-ends chains, strong relationships were found between the attribute pleasant and safe environment that the mall provides and the benefits comfort and convenience and peace of mind and safety both at $71 \%$ ). And in turn, comfort and convenience $(65 \%)$ as well as Peace of mind and safety (60\%) presented strong relationships at the most abstract level of goals with quality of life.

The variety of shops (83\%) and the food options (79\%) are also related to the consequence of practicality, associated by men with the desired end state of independence 
(56\%). Men also show a need for recognition and acceptance, final state benefit related to social life $(58 \%)$ and, in the most concrete level of the chain, with dining options $(52 \%)$, leisure options (54\%) and the public who attend the malls (54\%).

Almost half of men are orientated by utilitarian motivation (45.9\%) when going to the mall. This characteristic is reflected in the hierarchy of goals in the utmost importance that is given to the sense of autonomy and independence associated with practicality that the mall provides due to the variety of shops and food options. It is a group that seeks to resolve their problems in a short time, taking advantage of the ease of access and the parking facilities and of the pleasant and safe environment that the mall offers.

By analysing the women's Hierarchichal Value Map (figure 2) we can verify that for around $75 \%$ of women, the options of food and leisure that the malls have to offer provide the benefit of family life which in turn is associated with family harmony (71\%).

As for men, family harmony is also perceived as a result of the possibility of conciliate interests (69\%), which is possible due to the variety of shops (74\%), dining options (77\%) and leisure $(69 \%)$ that the mall provides.

The variety of shops is the attribute that shows stronger relationships between women, providing both benefits of problem solving as: practicality (92\%), price comparison (82\%) and time saving (79\%) as benefits associated with value expression goals: conciliate interests (74\%), being up to date with fashion trends (76\%), pleasure and satisfaction (62\%).

Women also demonstrate an intrinsic motivation for life quality, mainly related to the benefits of comfort and convenience (70\%) and peace of mind and safety (65\%), both strongly associated with the pleasant and safe environment that the mall provides $(71 \%$ and $61 \%$ respectively). 


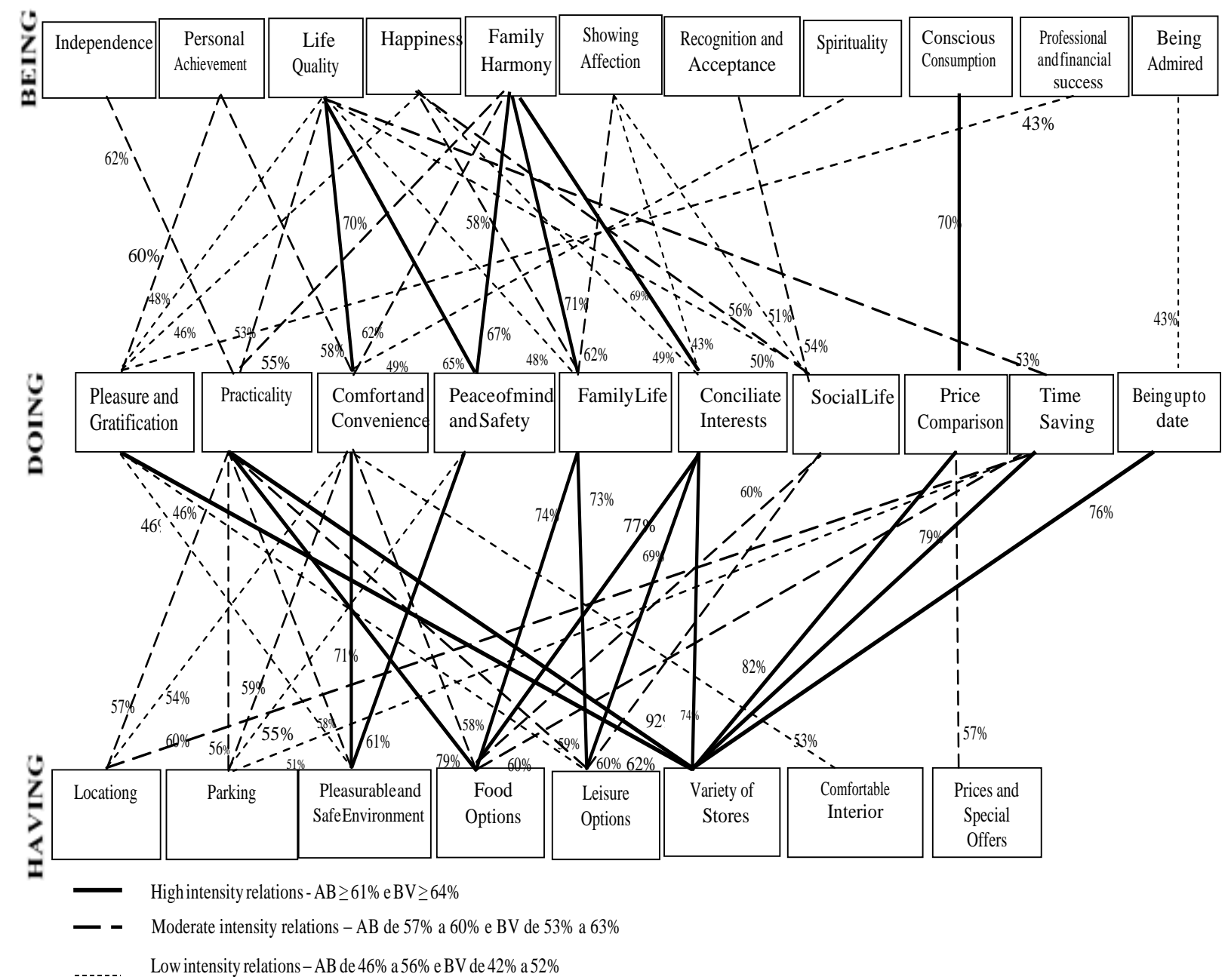

Basis: 457 female respondents

Figure 2: Hierarchical Value Map - Women

Source: Developed by authors

Women's HVM presents relationships that were highlighted in the men's HVM, as the benefit of being up to date with fashion trends and a higher purpose of life that is to be admired (43\%), besides the relationship between pleasure and gratification with the life project professional and financial success (43\%).

Women present a predominant mixed (40\%) and hedonic (31.7\%) motivation when going to the mall, which stands out in the relationship of the hierarchy of goals that are more orientated towards pleasure, gratification, life quality and personal fulfillment.

\section{FINAL CONSIDERATIONS}

This study has as its main contribution for the field of consumer behavior studies the contrast of the hierarchy of goals between men and women in a complex retail environment such as the shopping mall. Until then the literature of the hierarchy of goals presented studies focusing on specific products or services and on small retail stores such as convenience stores 
(LEE; ARIELY, 2006). This study extrapolated the scope of the analysis to a more extensive experience of consumption which is visiting shopping malls, where men and women can carry out different activities. The focus is not on identifying why the consumer buys the product or why they choose the service (as most of the studies have been conducted so far) but, on identifying why men and women choose the mall to perform their spending goals and how relations between attributes, benefits and personal values in different situations occur.

The results show that men and women go to the mall with different motivations which in turn, presented distinct goal structures. Men are orientated more by utilitarian motivation (45.9\%), while women go to the mall mainly driven by mixed (40\%) and hedonic $(31.7 \%)$ motivation. This difference in motivational orientation impacts in the way men and women perceive the benefits associated with the attributes and characteristics of the shopping mall and what are the life projects and personal values that guide their decisions and choices.

The more utilitarian orientation, present in men, makes them more focused on performing tasks, valuing the pleasant and safe environment of the mall and the facilities that the project provides in terms of parking and location. The variety of shops and the leisure and food options are features that provide benefits of practicality, comfort and convenience, family life and conciliation of interests. On a more abstract level, they seek for family harmony, recognition and acceptance both within the family and social framework, life quality and independence.

Women on the other hand have a wider relationship with shopping malls, once they attend malls to perform both tasks and to solve problems as well as to seek experiences of consumption. Driven mainly by hedonic goals, they value comfort, tranquility and the pleasure that malls provide. For them, the same characteristics - variety of shops, leisure and dining options - are associated with a wider range of benefits such as: pleasure and gratification practicality, time maximization, being up to date with trends fashion as well as conciliate interests and family life. With regard to the more abstract goals, besides the aspects devoted to the family as family harmony and showing affection, women also present more individualistic relations such as being admired, having professional and financial success and the search for spirituality and inner peace.

Although $85 \%$ of shopping mall consumers have access to the internet (IBOPE, 2013), the sample by accession obtained by digital means, is the main limitation to this study, which hinders the external validation of the results. Another limitation is that the study did not focus 
on the analysis of the mechanisms of goals formation in shopping malls. The concern was to understand the hierarchy of goals and the associations between the levels and not on goal setting. Understanding goal setting as the "motivational process where the consumer has to decide whether to pursue or not a certain goal or having to choose between conflicting goals" (BAUMGARTNER; PIETERS, 2008 p.373) new studies that seek to understand how the stimulus of the retail environment should be proposed, like the social influences and the previous experiences with a particular mall interfere in the formation of goals and with the consumer's effort to achieve them.

Since the shopping centers occupy a prominent place in the routine of consumers, being frequented for shopping, dining and entertainment, it is necessary to expand and to constantly innovate the strategies of the tenant mix and to review the structural and related aspects to the retail environment, seeking to fulfill both utilitarian goals related to problem solving as hedonic goals related to consuming experiences.

\section{REFERENCES}

ABRASCE. Associação Brasileira de Shopping Centers. Disponível em:

<http://www.abrasce.com.br/gr_numeros.htm>. Acesso em: mar. 2010; set; 2011; fev. 2013; dez. 2014.

ARIELY, D. Previsivelmente irracional: as forças ocultas que formam as nossas decisões. Rio de Janeiro: Elsevier, 2008.

BABIN, B.; DARDEN, W.; GRIFFIN, M. Work and/or fun: measuring hedonic and utilitarian shopping value. Journal of Consumer Research, v.20, p.644-656, 1994.

BAGOZZI, R.; DHOLAKIA, U. Goal setting and goal striving in consumer behavior. Journal of Marketing, v. 63, p. 19-32, 1999.

BANDURA, A. Social foundations of thought and action: a social cognitive theory. Englewood Cliffs, N.J: Prentice-Hall, 1986.

BARDIN, L. Análise de conteúdo. Lisboa: Ed.70, 1994.

BARLETTA, M.. Marketing para mulheres: como entender e aumentar sua participação no maior segmento do mercado. Rio de Janeiro: Ed. Campus, 2006.

BAUMGARTNER, H.; PIETERS, R. Goal-directed consumer behavior. In: HAUGTVEDT, C.; HERR, P.; KARDES, F. Handbook of consumer psycology. 2008. p. 367-392.

BLOCH, P.; RIDGWAY, N.; DAWSON, S. The shopping mall as consumer habitat. Journal of Retailing, v. 70, p. 29-38, 1994..

BOTTI, S.; MCGILL, A. The locus of choice: personal causality and satisfaction with hedonic and utilitarian Decisions. Journal of Consumer Research, v. 37, p. 1065-1078, 2011. 
BYRNE, B. Structural equation modeling with AMOS: basic concepts, applications, and programming.. Mahwah, New Jersey: Lawrence Erlbaum Associates, Inc Publishers, 2001. (Multivariate Applications books series).

COBANOGLU, C.; COBANOGLU, N. The effect of incentives in web surveys: application and ethical considerations. International Journal of Market Research, v. 4, p. 475-488, 2003.

DAVIS, R; LANG, B; SAN DIEGO, J. How gender affects the relationship between hedonic shopping motivation and purchase intentions? Journal of Consumer Behavior, v. 13, p. 18-30, 2014.

EL-ADLY, M. Shopping malls attractiveness: a segmentation approach. International Journal of Retail \& Distribution Management, v. 35, p. 936-950, 2007.

ENGEL, J., BLACKWELL, R., MINIARD, P. Comportamento do consumidor. Rio de Janeiro: LTC, 2000.

ESCUDERO, F.; PRADO, P. Análise das metas do consumidor: uma contribuição metodológica. RAE-Eletrônica, v. 7, n. 2, p. 22, 2008.

EVRARD, Y.; PRAS, B.; ROUX, E. Market: foundements et méthodes des recherches en marketing. 4. ed. France: Dunod, 2009.

FLICK, U. Uma introdução à pesquisa qualitativa. Porto Alegre: Bookman, 2004.

GABARINO, E; JOHNSON, M. Effects of consumer goals on attribute weighting, overall satisfaction, and product usage. Psychology \& Marketing, v. 18, p. 929-949, 2001.

GARBARINO, E; STRAHILEVITZ, M. Gender differences in the perceived risk of buying online and the effects of receiving a site recommendation. Journal of Business Research, v. 57, p. 768-775, 2004.

GORITZ, A. Incentives in web studies: methodological issues and a review. International Journal of Internet Science, v. 1, p. 58-70, 2006.

GUTMAN, J. A means-end chain model based on consumer categorization processes. Journal of Marketing, v. 46, p. 60-72, 1982.

GUTMAN, J. Means-end chains as goal hierarchies. Psychology \& Marketing, v. 14, p. 545-560, 1997.

HAIR JUNIOR, J. et al. Análise multivariada de dados. 5. ed. Porto Alegre. Artmed, 2005.

HASTREITER, S.; MARCHETTI, R. Looking for the hierarchical structure that drives Brazilian consumers decisions in shopping centers. In: EUROPEAN MARKETING ACADEMY (EMAC), 42., 2013, Istanbul (TUR). Anais... Istanbul: Istanbul Technical University, 2013. p. 382-389.

HEISLEY, D.; LEVY, S. Autodriving: a photoelicitation technique. Journal of consumer Research, v. 18 , p. 257-272, 1991. 
HESS, J.; MARCHETTI, R. Hierarchy of goals in food purchase: the contrast between Brazilian women from low and high income classes. In: 4th annual Summit on Peace and Prosperity through Trade and Commerce, centering on C.K. Prahalad's Legacy: Business for Poverty Alleviation. San Diego: University of San Diego, v. 4, p. 1-30, 2011.

HIRSCHMAN, E.; HOLBROOK, M. Hedonic consumption: emerging concepts, methods and propositions. Journal of Marketing, v. 46, p. 92-101, 1982.

HOFSTEDE, T. et al. An investigation into the association pattern technique as a quantitative approach to measuring means-end chains. Journal of Research in Marketing, v. 15, p. 37-50, 1998.

HOUSTON, M.; WALKER, B. Self-relevance and purchase goals: mapping a consumer decision. Academy of Marketing Science, v. 24, p. 232-245, 1996.

HUFFMAN, C.; RATNESHWAR, S.; MICK, D. Consumer goal structures and goal-determination process: an integrative framework. In: RATNESHWAR, S.; MICK, D.; HUFFMAN, C. The why of consumption. 2000. p. 9-34.

IBOPE. 85\% dos internautas frequentam shopping centers. Disponível em: <http://ibope.com.br/ptbr/solucoes/geonegocios/shopping/Boletim\%20Informativo\%20de\%20Shopping\%20Center/Geonot\% C3\%ADcias_maio\%202013.pdf>. Acesso em: 08 set. 2014.

ICSC. International Council of Shopping Centers. Disponível em: <http://www.icsc.org/research/index.php>. Acesso em: 10 mar. 2012.

KHAN, U.; DHAR, R.; WERTENBROCH, K. A Behavioral decision theoretic perspective on hedonic and utilitarian choice. In: RATNESHWAR, S.; MICK, D. Inside consumption: consumer motives, goals, and desires. Great Britain: Routledge, 2005. p. 144-165.

KRAFT, H.; WEBER, J. A look at gender differences and marketing implications. International Journal of Business and Social Science, v. 3, p. 247-253, 2012.

LEE, L; ARIELY, D. (2006) Shopping goals, goal concreteness, and conditional promotions. Journal of Consumer Research, v. 33, p. 60-70, 2006.

LIGAS, M. People, products, and pursuits: exploring the relationship between consumer goals and product meanings. Psychology \& Marketing, v. 17, p. 983-1003, 2000.

MCINTOSH, W. When does goal nonattainment lead to negative emotional reactions, and when doesn't it?: the role of linking and rumination. In: MARTIN, L.; TESSER, A. (Eds.). Striving and feeling: interactions among goals, affect, and self-regulation. New Jersey: Lawrence Erlbaum Associates Inc. Publishers, 1996.

MICHON, R.; CHEBAT, J. Cross-cultural mall shopping values and habitats. A comparison between English- and French-speaking Canadians. Journal of Business Research, v. 57, p. 883-892, 2004.

MICK, D.; BUHL, C. A Meaning-based model of advertising experiences. Journal of Consumer Research, v. 19, p. 317-338, 1992. 
MOSKOWITZ, G.; GRANT, H. Four themes in the study of goals. In: The psychology of goals. New York: The Guilford Press, 2009.

PARK, W.; SMITH, D. Product-level choice: a top-down or bottom-up process? Journal of Consumer Research, v. 16, p. 289-299, 1989.

PATTON, M. Qualitative research and evaluation methods. Thousand Oaks, California: Sage Publications, Inc., 2002.

REYNOLDS, T.; GUTMAN, J. Laddering theory, method, analysis and interpretation. Journal of Advertising Research, p. 11-31, 1998.

SCHAUERTE, T. Investigating consumer perceptions by applying the extended association pattern technique: a study on wooden multistory houses. Göteborg, Intellecta Infolog, Växjö University, Sweden, 2009.

UNDERHILL, P. Vamos às compras! A ciência do consumo nos mercados globais. São Paulo: Campus, 2009.

Schuster, 2010.

What women want: the global marketing turns female friendly. New York: Simon \&

VAN OSSELAER, S. et al. Choice based on goals. Marketing Letters, v. 16, n. 3/4, p.335-346, 2005.

ZALTMAN, G. Rethinking market research: putting people back. Journal of Marketing Research, v. 34, p. 424-437, 1997.

ZHANG, Y.; FEICK, L.; MITTAL, V. How males and females differ in their likelihood of transmitting negative word of mouth. Journal of Consumer Research, v. 40, p. 1097-1108, 2014. 